\title{
Uji Biologis Iodium dari Rumput Laut (Eucheuma cottonii L.) daı Pengaruhnya terhadap Kemampuan Belajar Tikus Percobaan
}

\author{
Iodine Biological Test from Seaweed (Eucheuma cottonii $\mathbf{L}$.) and its Influence to Rats \\ Learning Ability
}

\author{
Made Astawan $^{1 *}$, Tutik Wresdiyati ${ }^{2}$, Komari $^{3}$, Ni Nengah Lasmiati ${ }^{1}$ \\ ${ }^{1}$ Departemen Teknologi Pangan dan Gizi, Fakultas Teknologi Pertanian, Institut Pertanian Bogor, Kampus IPB \\ Darmaga, P.O. Box 220, Bogor 16002. e-mail: astawan@indo.net.id * Penulis untuk korespondensi \\ ${ }^{2}$ Departemen Anatomi, Fakultas Kedokteran Hewan, Institut Pertanian Bogor, Darmaga 16680. \\ ${ }^{3}$ Pusat Penelitian dan Pengembangan Gizi, Jl. Dr. Semeru 63, Bogor 16112
}

\begin{abstract}
Intelligent is one of human quality factors that can be influenced by nutrition. Iodine is one of trace element nutrition that necessary for intelligent level. The purpose of this research was to learn the effect of seaweed as iodine source on rats learning ability. The rats were divided into four groups based on the ratio: A (without potassium iodide/KIseaweed flour (SF) 0\%), B (with KI-SF 0\%), C (without KI-SF 5\%) and D (without KISF $10 \%$ ). The ratio had no significant effect on rats growth, but significant on iodine retention, neuron cell number and rats learning ability. Iodine retention value had a positive correlation with the neuron cell number. The neuron cell number of group A, $B, C$ and $D$ were $72.83,89.33,93.92$ and 100.83 cells per view area, respectively. The number of neuron cells gave a significant influence on rats learning ability. Total time needed by the rats in food retrieval test for the group $A, B, C$ and $D$ was $57.84,38.17$, 33.39 and 20.55 seconds, respectively. The more neuron cell number, the more learning ability.
\end{abstract}

Key words: seaweed, iodine, learning ability, rat, neuron

Diterima: 27 Februari 2004, disetujui: 06 Mei 2004

\section{Pendahuluan}

Kecerdasan merupakan salah satu parameter penting untuk menentukan kualitas sumberdaya manusia. Potensi kecerdasan seseorang dapat terwujud bila didukung oleh kondisi lingkungan yang memadai serta berbagai faktor lain. Susanto (2000) menyatakan bahwa pertumbuhan dan kecerdasan dipengaruhi oleh faktor internal, yaitu: genetik, hormonal dan metabolik serta faktor eksternal, yaitu: lingkungan fisik dan biologik, sosial, ekonomi, budaya serta pangan dan gizi.

Status gizi sangat berkaitan erat dengan kemampuan organ otak secara utuh dan sempurna, baik struktur maupun fungsinya Proses tumbuh kembang otak sangat unik karena otak berkembang sempurna jaul sebelum pertumbuhan badan berhenti. Ota mengalami tingkat perkembangan mulai pad stadium pertumbuhan janin dalam kandunga dan sangat pesat pada stadium intrauterin da postnatal sampai usia tiga tahun. Apabila pad proses tersebut kecukupan zat gizi ibu tidal terpenuhi maka diperkirakan perkembanga otak bayi tidak berlangsung sempurna Perkembangan organ otak yang tidak sempurn dapat menurunkan kualitas sumberday manusia, terutama daya ingat dan tingka kecerdasan anak hingga dewasa. 
Proses tumbuh kembang otak terjadi dalam tiga tahap yaitu tahap pertama disebut hiperplasia, suatu tahap dimana sel-sel otak membelah diri sehingga jumlah sel-sel otak bertambah dengan cepat. Tahap kedua disebut hiperplasia dan hipertrofi, selama tahap ini proses pembelahan sel semakin berkurang, diikuti dengan peningkatan pemekaran dan pematangan sel otak. Tahap ketiga disebut hipertrofi, yaitu saat pembelahan sel-sel otak berhenti, tetapi terus terjadi peningkatan ukuran dan penyempurnaan fungsi sel otak sehingga mencapai pematangan sel yang penuh.

Salah satu zat gizi yang sangat berperan penting terhadap kecerdasan adalah iodium yang termasuk dalam komponen trace element. Dampak negatif kekurangan iodium mempunyai spektrum yang sangat luas, di antaranya adalah: pembesaran kelenjar gondok, kretin neurologi, hambatan neuromotor (perkembangan syaraf penggerak) dan kondisi tuli disertai bisu (deaf mutism). Akibatnya penderita menjadi terganggu tingkat kecerdasannya, lamban dan kurang bergairah sehingga sulit untuk dididik dan dimotivasi (Sediaoetama, 1991).

Mineral iodium dapat diperoleh dari berbagai sumber seperti misalnya garam beriodium dan suntikan lopiodol. Namun karena kecenderungan masyarakat saat ini lebih mengarah pada sumber alami (back to nature), maka timbul upaya untuk mencari dan mengidentifikasi jenis pangan sumber iodium.

Sumber mineral iodium alami dapat diperoleh dari berbagai makanan hasil laut. Salah satu komoditi dari laut yang disinyalir sebagai sumber iodium yang sangat bermakna adalah rumput laut. Menurut Winarno (1997) makanan-makanan dari laut dan ganggang laut merupakan sumber iodium yang penting. Rumput laut mengandung iodium yang cukup potensial sehingga sangat menarik untuk diteliti lebih lanjut guna memperkaya khasanah ilmu pengetahuan.

Tujuan umum dari penelitian ini adalah untuk mengetahui ketersediaan biologis iodium dari rumput laut (Eucheuma cottonii) dan pengaruhnya terhadap kemampuan belajar tikus percobaan. Tujuan khusus dari penelitian ini adalah untuk mengukur daya serap dan retensi iodium dari rumput laut jenis Eucheuma cottonii, menghitung jumlah sel neuron otak, serta menentukan kemampuan belajar tikus percobaan.

\section{Metode Penelitian}

Penelitian diawali dengan pembuatan tepung rumput laut (TRL) dan analisis kimia terhadap TRL yang dihasilkan, meliputi: kadar air, abu, lemak, protein, karbohidrat (metode AOAC, 1995), kadar serat pangan dengan metode enzimatik (Asp et al., 1983), serta analisis kadar iodium dengan metode spektrofotometri (Raghuramulu et al., 1983).

Pada penelitian ini digunakan tikus percobaan jenis Sprague Dawley umur 3 minggu, yang dibedakan menjadi empat kelompok (masing-masing lima ekor) berdasarkan jenis ransumnya yaitu: ransum tanpa kalium iodida (KI)-tepung rumput laut (TRL) $0 \%$ sebagai kontrol negatif, ransum dengan KI-TRL $0 \%$ sebagai kontrol positif, ransum tanpa KI- TRL 5\%, dan ransum tanpa KI- TRL 10\%. Komposisi ransum secara lengkap dapat dilihat pada Tabel 1. Penambahan TRL sebesar 5\% dan 10\% ke dalam ransum dimaksudkan sebagai pengganti kalium iodida (KI) yang biasanya ditambahkan dalam bentuk multimineral.

Pengukuran berat badan keempat kelompok tikus percobaan dilakukan setiap dua hari sekali dimulai dari awal perlakuan sampai hari terakhir. Selain itu dilakukan juga pengumpulan feses dan urin. Selanjutnya dilakukan analisis iodium yang terdapat pada urin dan feses. Penghitungan daya serap dan retensi iodium dilakukan dengan cara menganalisis total iodium yang dikonsumsi, iodium pada urin, serta iodium pada feses tikus percobaan, sebagai berikut:

\begin{tabular}{c}
\hline Daya serap iodium $=\frac{\mathrm{I}_{\text {konsumsi }}-\mathrm{I}_{\text {feses }}}{---------------} \times 100 \%$ \\
$\mathrm{I}_{\text {konsumsi }}$ \\
Retensi iodium $=$ \\
$\mathrm{I}_{\text {konsumsi }}-\mathrm{I}_{\text {feses }}-\mathrm{I}_{\text {urin }}$ \\
$\mathrm{I}_{\text {konsumsi }}$ \\
\hline
\end{tabular}


Pengukuran kemampuan belajar tikus percobaan dilakukan dengan menggunakan uji mendapatkan kembali makanan (food retrieval test) yang dikembangkan oleh Suprijana (1992) dengan menggunakan labirin. Prinsip uji ini adalah mengukur waktu tempuh untuk mendapatkan makanan yang diletakkan pada posisi tertentu.
Penghitungan jumlah sel neuro dilakukan melalui pewarnaan Hematoksilin Eosin (HE) dan pengamatan denga menggunakan mikroskop yang dilengkap kamera. Jumlah sel neuron dihitung per lapan, pandang, masing-masing sepuluh kali ulanga dengan pembesaran 110 kali.

Tabel 1. Komposisi ransum tikus percobaan

\begin{tabular}{lcccc}
\hline \multicolumn{1}{c}{ Bahan (\%) } & Tanpa KI-TRL & Dengan KI-TRL & Tanpa KI- TRL & Tanpa KI- TRL \\
& $0 \%$ & $0 \%$ & $5 \%$ & $10 \%$ \\
& & & & 10.5 \\
\hline \hline Kasein & 10.5 & 10.5 & 10.5 & 7.9 \\
Minyak & 7.9 & 7.9 & 7.9 & 4.8 \\
Multimineral* & 4.8 & 4.8 & 4.8 & 1.0 \\
Multivitamin & 1.0 & 1.0 & 1.0 & 1.0 \\
Selulosa & 1.0 & 1.0 & 1.0 & 3.8 \\
Air & 3.8 & 3.8 & 3.8 & 10.0 \\
TRL & - & - & 5.0 & 61.0 \\
Pati & 71.0 & 71.0 & 66.0 & \\
\hline \hline
\end{tabular}

Keterangan : KI = kalium iodida, $\mathrm{TRL}=$ tepung rumput laut

* Khusus untuk perlakuan tanpa KI, tidak ditambahkan kalium iodide ke dalam campuran multimineral

\section{Hasil dan Pembahasan}

\section{Kadar Iodium Ransum}

Analisis kimiawi yang dilakukan terhadap tepung rumput laut yaitu kadar air, abu, lemak, protein, karbohidrat, serat pangan dan iodium, disajikan pada Tabel 2. Perbedaan sumber iodium (KI atau TRL) serta jumlah TRL yang ditambahkan ke dalam ransum (5\% atau $10 \%$ ) menghasilkan kadar iodium yang berbeda-beda pada ransum, seperti yang terlihat pada Gambar 1.

Gambar 1 menunjukkan kadar iodium ransum tanpa KI-tanpa TRL (kontrol negatif) paling rendah yaitu 5,78 ppm. Ransum tanpa KI- TRL $10 \%$ memiliki kadar iodium paling tinggi yaitu 37,76 ppm. Ransum dengan KITRL $0 \%$ (kontrol positif) dan ransum tanpa KI-TRL $5 \%$ mempunyai kadar iodium yang relatif sama, yaitu masing-masing sebesar 23,05 ppm dan 22,96 ppm. Dengan demikian dapat dikatakan bahwa penambahan TRL sebesar 5\% dapat menggantikan KI dari multimineral.

\section{Pertumbuhan Tikus Percobaan}

Pengukuran berat badan tikus selam pengamatan menunjukkan adanya peningkata pada semua perlakuan. Zat gizi seper karbohidrat (pati dan gula), protein dan lemal di dalam tubuh akan dioksidasi menjadi energi Makin banyak zat gizi tersebut dikonsumsi makin banyak pula energi yang dihasilkan Energi yang tidak terpakai akan disimpan d dalam tubuh berupa timbunan lemak, yan berdampak pada peningkatan berat badan.

Analisis sidik ragam menunjukka bahwa pertambahan berat badan tiku percobaan antarperlakuan ransum (termasu kontrol positif) tidak berbeda nyata $(p>0.05)$ Hal ini menunjukkan bahwa tikus percobaa yang digunakan untuk masing-masin perlakuan memiliki pertambahan berat bada yang relatif sama.

Dengan demikian maka semua respo yang ditimbulkan oleh tikus selama percobaa berlangsung, bukan disebabkan oleh kurangny asupan zat gizi makro (khususnya protein tetapi oleh perlakuan yang diberikan, yait kadar dan sumber iodium di dalam ransum. 
Uji Biologis Iodium dari Rumput Laut

Tabel 2. Komposisi kimia tepung rumput laut Eucheuma cottonii

\begin{tabular}{lc}
\hline \multicolumn{1}{c}{ Parameter } & Kadar \\
\hline \hline Kadar abu (\% bk) & 5.11 \\
Kadar protein (\% bk) & 5.43 \\
Kadar lemak (\% bk) & 1.47 \\
Kadar karbohidrat (\% bk) & 87.99 \\
Kadar serat pangan larut (\% bk) & 38.77 \\
Kadar serat pangan tidak larut (\%bk) & 43.17 \\
Kadar serat pangan total (\%bk) & 81.94 \\
Kadar iodium (ppm) & 54.59 \\
\hline \hline
\end{tabular}

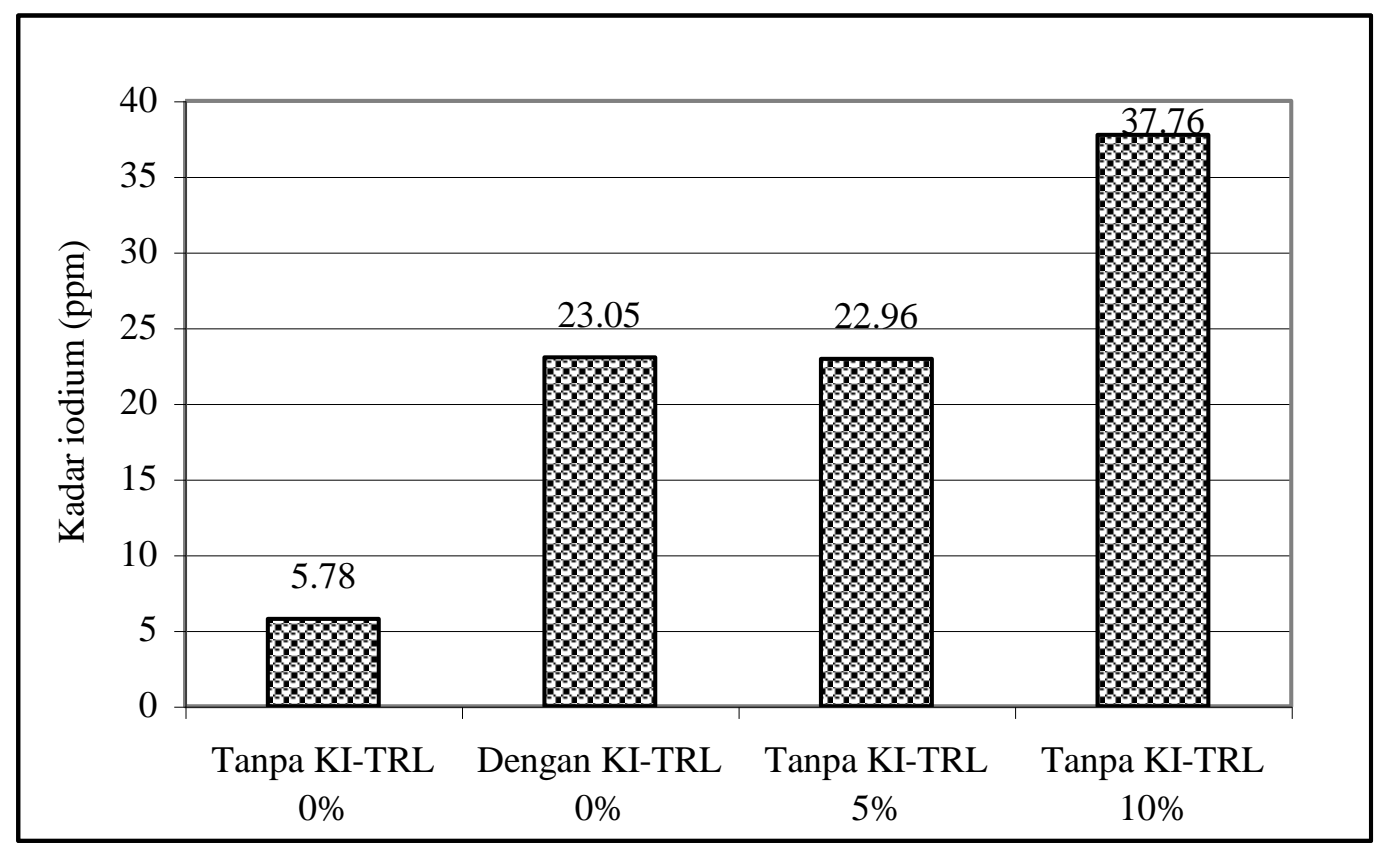

Gambar 1. Kadar iodium (ppm) pada keempat jenis ransum

\section{Daya Serap dan Retensi Iodium}

Hasil pengamatan terhadap rata-rata jumlah iodium yang dikonsumsi dari ransum, kadar iodium pada feses dan urin, serta daya serap, retensi dan jumlah iodium yang ditahan oleh tubuh tikus percobaan dapat dilihat pada Tabel 3. Analisis sidik ragam menunjukkan bahwa perlakuan ransum berpengaruh sangat nyata $(\mathrm{p}<0.01)$ terhadap retensi iodium (mikrogram per hari) di dalam tubuh tikus.

Pada Tabel 3 terlihat bahwa persentase daya serap iodium paling tinggi $(94,80 \%)$ ditunjukkan oleh tikus perlakuan tanpa KI-TRL $0 \%$, sedangkan daya serap terendah $(83,81 \%)$ terdapat pada tikus yang diberi perlakuan tanpa KI-TRL 10\%. Dalam metabolisme iodium akan terjadi keseimbangan, yaitu semakin tinggi asupan iodium ke dalam tubuh maka persentase daya serap iodium akan semakin rendah, sebaliknya semakin rendah asupan iodium maka persentase daya serap semakin tinggi (Hetzel dan Clugston, 1994).

Retensi iodium paling tinggi (358,09 $\mu \mathrm{g} / \mathrm{hr}$ ) ditunjukkan oleh kelompok tikus yang diberi perlakuan D (tanpa KI-TRL 10\%) dan retensi terendah $(43,75 \mu \mathrm{g} / \mathrm{hr})$ pada kelompok tikus perlakuan A (tanpa KI-TRL 0\%). Perbedaan persentase daya serap dan retensi iodium disebabkan oleh adanya perbedaan antara jumlah iodium yang dikonsumsi dengan jumlah iodium yang keluar melalui feses dan urin. Meskipun daya serap iodium tertinggi ditunjukkan oleh kelompok tikus perlakuan A (tanpa KI-TRL 0\%), namun retensi iodium tertinggi ditunjukkan oleh perlakuan D (tanpa KI-TRL 10\%). Hal ini disebabkan oleh lebih tingginya jumlah konsumsi iodium pada kelompok tanpa KI-TRL 10\% (yaitu 434,06 
$\mu \mathrm{g} / \mathrm{hr}$ ) dibandingkan kelompok tanpa KI-TRL $0 \%$ (yaitu sebesar 63,42 $\mu \mathrm{g} / \mathrm{hr}$ ).

Tabel 3 menunjukkan bahwa pada perlakuan ransum yang tidak ditambahkan TRL (tanpa KI-TRL 0\%; dengan KI-TRL 0\%), jumlah iodium yang dikeluarkan lebih banyak melalui urin dibandingkan feses. Hal ini sesuai dengan pendapat Mahan dan Stump (1996) bahwa ekskresi iodium yang paling utama adalah melalui urin dan dalam jumlah kecil keluar melalui feses (berasal dari empedu).

Pada tikus yang diberi perlakuan penambahan TRL (tanpa KI-TRL 5\%; tanpa KI-TRL 10\%) terjadi hal sebaliknya yaitu ekskresi iodium lebih banyak melalui feses dibandingkan urin. Hal tersebut disebabkan oleh kandungan serat pangan pada TRL yan dapat mengikat mineral khususnya iodium sehingga ekskresi iodium lebih banyak terjad melalui feses. Jumlah iodium yang diikat fese akan semakin tinggi dengan semakin tingginy kandungan serat pangan di dalam ransum.

Lebih lanjut Astawan dan Palupi (1990 menyatakan bahwa kelarutan mineral dapa menurun sebagai akibat terjadinya interaks ionik atau pembentukan kompleks atau khela dengan serat pangan. Beberapa hasil stud secara in vitro menunjukkan bahwa sera pangan dapat mengikat berbagai macan mineral dan menurunkan kelarutan sert ketersediaannya.

Tabel 3. Daya serap dan retensi iodium pada keempat jenis ransum

\begin{tabular}{|c|c|c|c|c|c|}
\hline \multirow[t]{2}{*}{ Perlakuan } & \multicolumn{3}{|c|}{ I Jumlah iodium $(\mu \mathrm{g} / \mathrm{hr})$} & \multirow{2}{*}{$\begin{array}{c}\text { Daya serap } \\
(\%)\end{array}$} & \multirow{2}{*}{$\begin{array}{l}\text { Retensi } \\
(\mu \mathrm{g} / \mathrm{hr})\end{array}$} \\
\hline & Konsumsi & Feses & Urin & & \\
\hline Tanpa KI-TRL 0\% & 63.42 & 3.11 & 16.57 & 94.80 & $43.75^{\mathrm{a}}$ \\
\hline KI-TRL $0 \%$ & 278.25 & 17.52 & 18.40 & 93.58 & $242.33^{c}$ \\
\hline Tanpa KI-TRL 5\% & 238.05 & 38.10 & 9.22 & 84.78 & $190.73^{b}$ \\
\hline Tanpa KI-TRL10\% & 434.06 & 70.09 & 5.88 & 83.81 & $358.09^{\mathrm{d}}$ \\
\hline
\end{tabular}

Keterangan : $a, b, c$ dan $d$ : huruf yang berbeda menandakan hasil uji Duncan terhadap retensi iodium sangat berbeda nyata $(\mathrm{p}<0.01)$

\section{Jumlah Sel Neuron Otak}

Otak merupakan organ vital bagi hewan dan manusia karena di sana pusat pengaturan semua sistem dalam tubuh. Analisis terhadap jumlah sel neuron otak dilakukan dengan cara menghitung jumlah sel neuron per lapang pandang. Pengamatan dilakukan pada bagian korteks serebri karena bagian ini mempunyai keunggulan dalam hal kemampuan untuk berpikir, berkomunikasi, mengingat, dan menganalisis input oleh sistem saraf pusat. Jenkins (1978) dikutip oleh Nurhidayat (1992) menyatakan bahwa korteks serebri merupakan pusat motor dan sensori dimana sel-sel neuron korteks mempunyai akson-akson yang berhubungan dengan bagian otak yang lain.

Pengamatan terhadap jumlah sel neuron dapat dipermudah dengan melakukan pewarnaan Hematoksilin-Eosin. Hematoksilin akan mewarnai inti sel sedangkan Eosin mewarnai sitoplasma. Hasil perhitungan jumlah sel neuron tikus per lapang pandang dengan pembesaran 110 kali dapat dilihat pad Gambar 2. Tidak terdapat perbedaan yan nyata antara jumlah sel neuron otak bagian kiı dan bagian kanan. Oleh karena itu pad penelitian selanjutnya yang dianalisis hany jumlah sel neuron pada otak bagian kiri.

Gambar 2 menunjukkan bahw perlakuan mengakibatkan perbedaan jumlah se neuron otak kiri tikus. Tikus perlakuan tanp KI-TRL 0\% (kontrol negatif) memiliki jumla sel neuron otak paling sedikit, diikuti ole perlakuan KI-TRL 0\% (kontrol positif); tanp KI-TRL 5\% dan perlakuan tanpa KI-TRL 10\% Hal yang mempengaruhi perbedaan jumlah se neuron otak yaitu perbedaan kadar iodium pad ransum. Semakin tinggi kadar iodium pad ransum maka jumlah sel neuronnya semaki banyak. Kadar iodium yang tinggi dapa meningkatkan produksi hormon tiroksin. Sala satu fungsi hormon tiroksin adalah membant meningkatkan pertumbuhan sel dan jaringan Neuron merupakan salah satu sel targe hormon tiroksin. Bila kadar iodium yan 
disuplai ke dalam tubuh lebih kecil dari kebutuhan normal maka pertumbuhan sel dan jaringan terhambat.

Hasil analisis sidik ragam menunjukkan bahwa perbedaan perlakuan kadar iodium pada ransum berpengaruh sangat nyata $(\mathrm{p}<0.01)$ terhadap jumlah sel neuron otak kiri tikus. Hasil uji beda Duncan menunjukkan bahwa tikus yang diberi perlakuan tanpa KI-TRL 0\% (kontrol negatif) memiliki jumlah sel neuron pada otak kiri paling sedikit $(77,42)$ dan berbeda nyata terhadap perlakuan ransum dengan KI-TRL 0\% (92,08); tanpa KI-TRL 5\% $(95,17)$ dan perlakuan tanpa KI-TRL $10 \%$ $(100,83)$. Sedangkan antara perlakuan kontrol potitif, TRL $5 \%$ dan TRL $10 \%$ tidak terdapat perbedaan jumlah sel neuron yang nyata. Hal ini menandakan bahwa penambahan TRL mampu menggantikan peranan biologis kalium iodida (KI) di dalam ransum. Sedikitnya jumlah sel neuron otak tikus pada perlakuan kontrol negatif diduga disebabkan oleh kondisi hipotiroidisme ringan, akibat sangat rendahnya sumber iodium di dalam ransum.

Ditinjau dari segi kerapatan dan penyebaran sel neuron, perlakuan tanpa KITRL 10\% menunjukkan kerapatan sel yang lebih tinggi dan tingkat penyebaran lebih merata, diikuti oleh perlakuan tanpa KI-TRL 5\%; perlakuan dengan KI-TRL $0 \%$ dan perlakuan tanpa KI-TRL 0\%. Hal ini sesuai dengan pernyataan Hetzel dan Potter yang dikutip oleh Djokomoeljanto (1993) bahwa pada domba yang mengalami defisiensi iodium, jumlah sel saraf dan kadar DNA pada otak berkurang, sehingga tingkat kerapatannya menjadi rendah. Untuk lebih jelasnya, struktur sel neuron korteks serebri pada otak besar tikus dapat dilihat dari Gambar 3. Sel neuron otak berbentuk bulat dan memiliki ekor yang merupakan akson (ditunjukkan oleh tanda panah).

\section{Jumlah Sel Neuron dan Kemampuan Belajar}

Proses belajar hewan dibagi dalam beberapa kategori yaitu kebiasaan, kondisional klasik, kondisional alat, tingkah laku bermain tiruan, belajar pengertian dan mengesankan suatu proses. Tikus mampu belajar sampai pada kategori alat seperti skinner box (Immelmann, 1980 dikutip oleh Nurhidayat, 1992).

Menurut Hinde (1970) dikutip oleh Nurhidayat (1992) proses belajar suatu spesies dipengaruhi oleh usia kritis belajar. Masingmasing hewan mempunyai usia kritis belajar yang berbeda. Tikus menunjukkan peningkatan dalam kemampuan exploratory behaviour dari usia 50-116 hari. Hasil uji kemampuan belajar dari keempat kelompok tikus percobaan dapat dilihat pada Gambar 4.

Pada metode ini, semakin cepat waktu yang ditempuh oleh tikus dari posisi awal hingga posisi akhir alat ukur, menunjukkan kemampuan belajar yang semakin baik. Hasil analisis sidik ragam menunjukkan bahwa perlakuan ransum memberikan pengaruh yang sangat nyata $(\mathrm{p}<0.01)$ terhadap kemampuan belajar tikus percobaan. Hasil uji beda Duncan menunjukkan bahwa tikus perlakuan ransum tanpa KI-TRL $10 \%$ memerlukan waktu tempuh yang paling cepat $(20,55$ detik) sedangkan perlakuan tanpa KI-TRL $0 \%$ paling lambat (57,84 detik). Hal ini menunjukkan bahwa kandungan iodium dalam ransum memberi pengaruh terhadap kemampuan belajar tikus. Waktu tempuh tikus perlakuan ransum dengan KI-TRL 0\% (39,17 detik) dan perlakuan tanpa KI-TRL 5\% (33,39 detik) secara statistik tidak berbeda nyata. Hal tersebut menunjukkan bahwa penambahan TRL sebesar 5\% dapat menggantikan fungsi biologis kalium iodida (KI) pada ransum.

Pengaruh perbedaan kadar iodium pada jaringan otak terlihat pada jumlah sel neuron korteks serebri yang berkorelasi positif terhadap kemampuan belajar tikus. Semakin banyak jumlah sel neuron otak maka semakin banyak memori yang dapat disimpan sehingga kemampuan belajarnya semakin baik. Selain itu, dengan semakin banyak jumlah sel neuron maka impuls-impuls saraf dapat disampaikan dalam waktu yang relatif lebih singkat. 


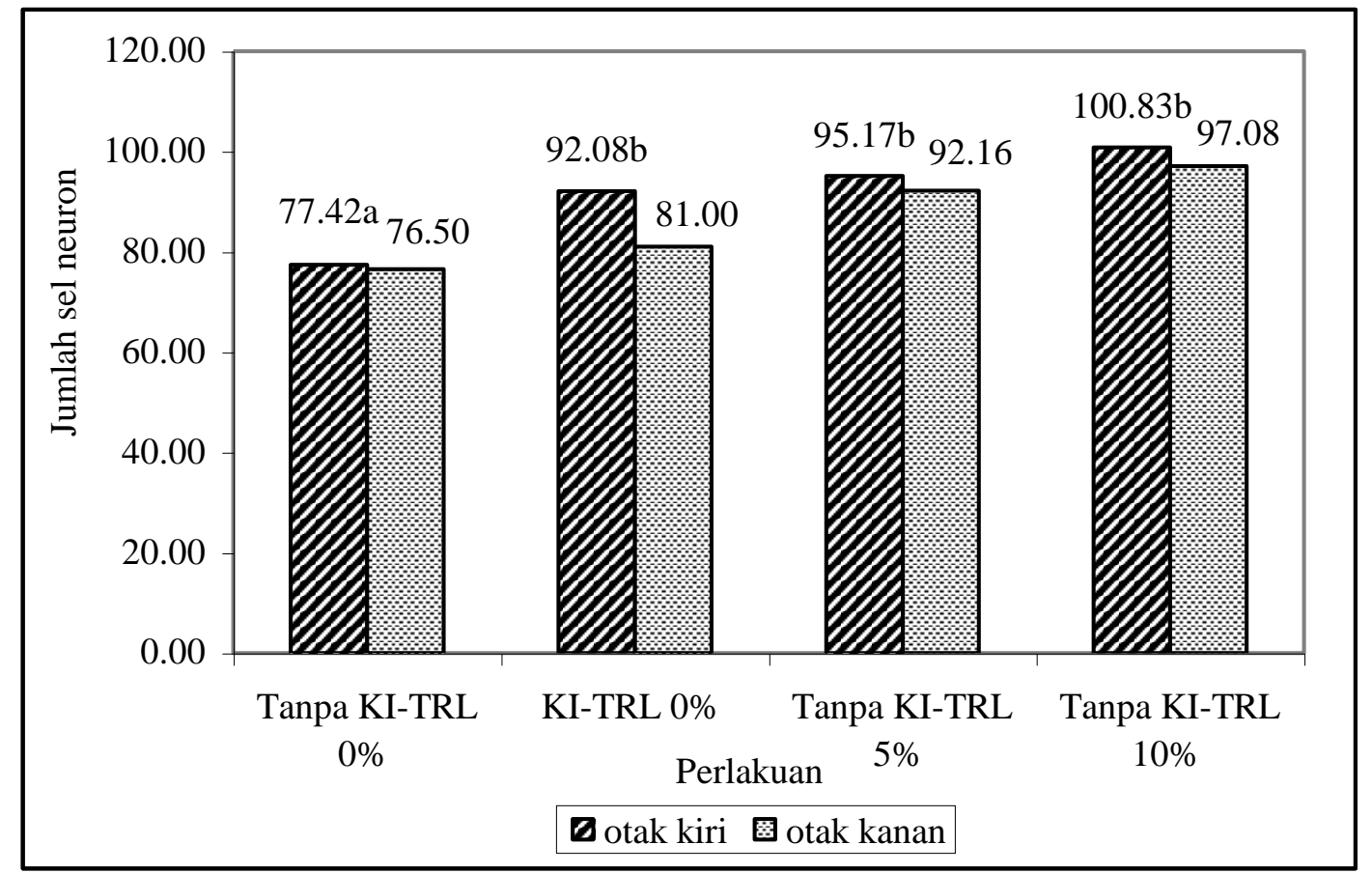

Gambar 2. Jumlah sel neuron otak (pembesaran 110x)

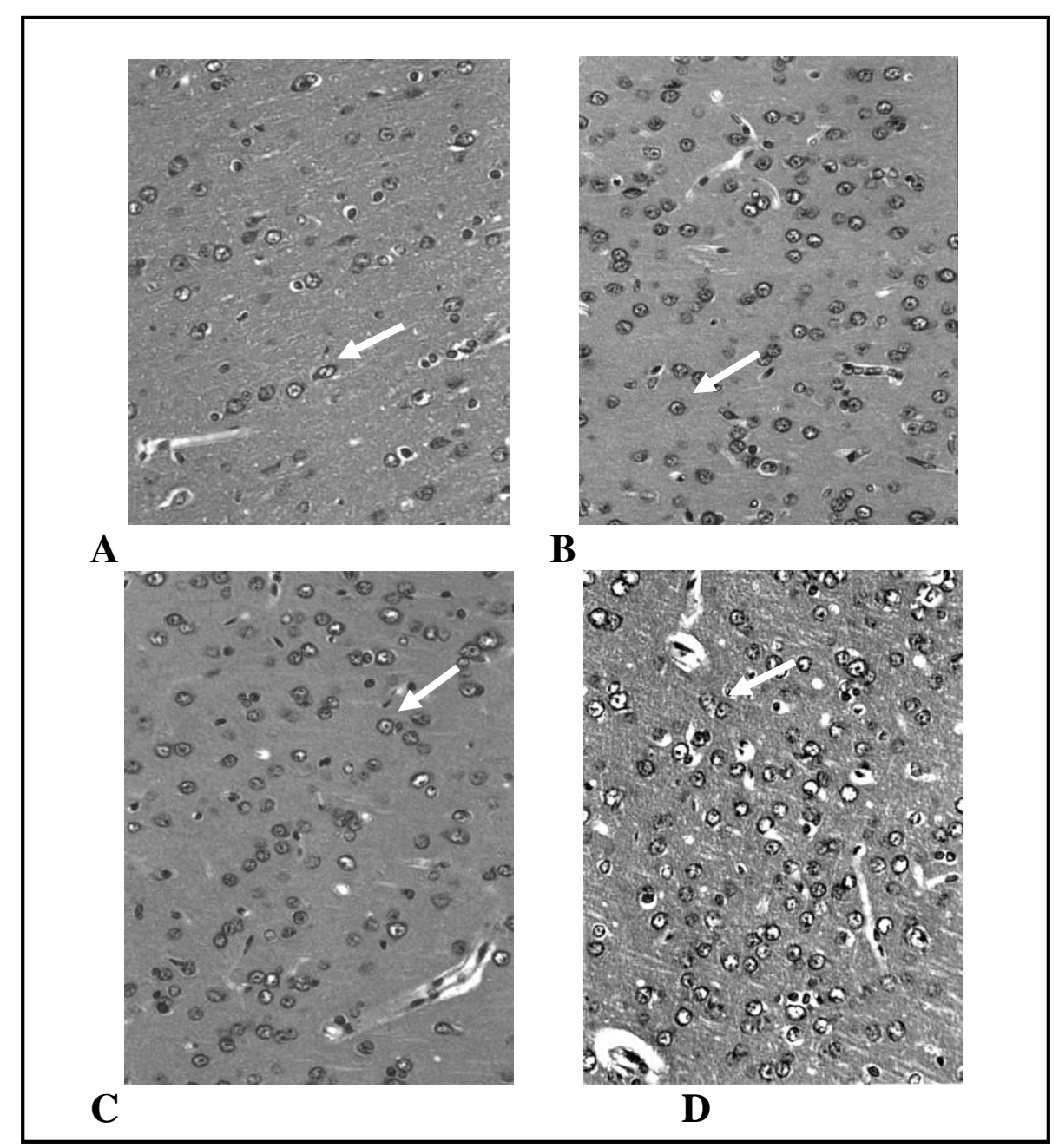

Gambar 3. Struktur sel neuron korteks serebri pada otak besar bagian kiri tikus percobaan (pembesaran 110x)

Keterangan : A : Ransum tanpa kalium iodida (KI)-tepung rumput laut (TRL) $0 \%$

B : Ransum dengan KI-TRL 0\%

C : Ransum tanpa KI-TRL 5\%

D : Ransum tanpa KI-TRL $10 \%$ 


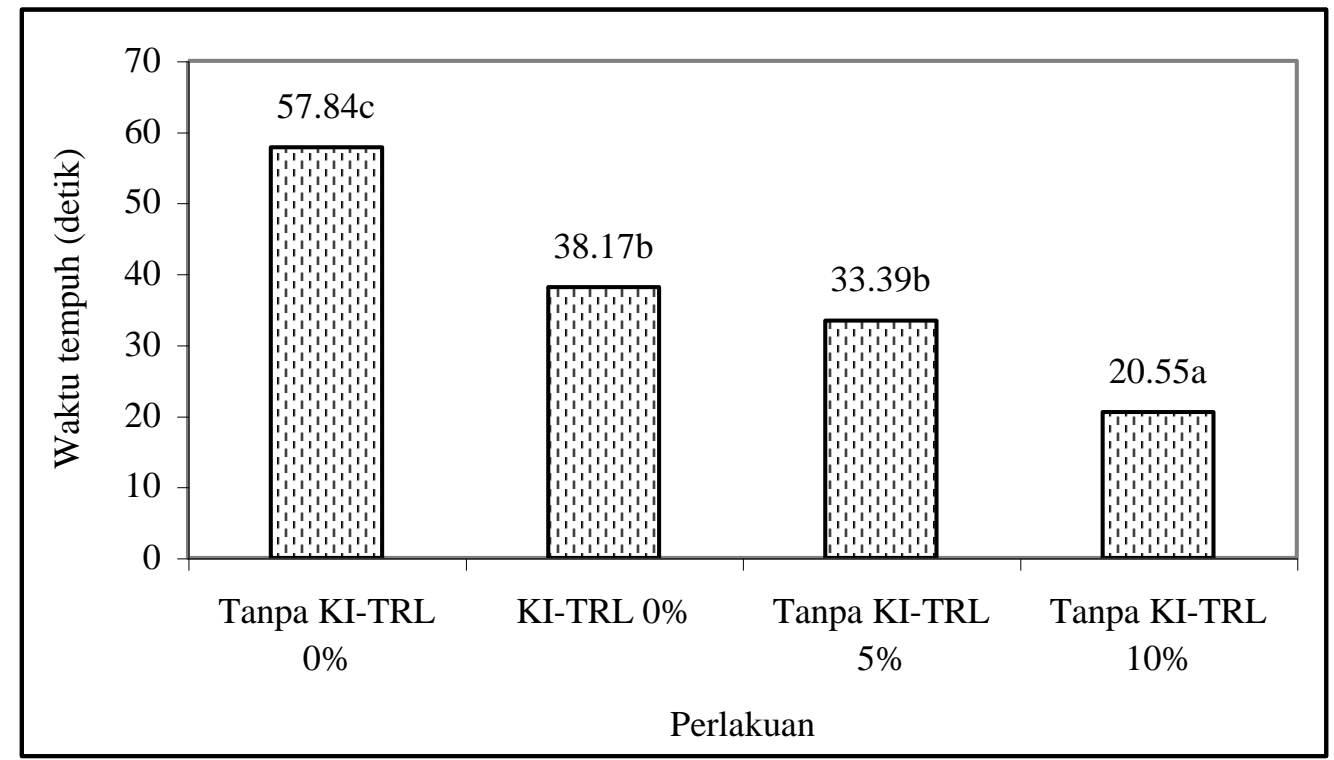

Gambar 4. Hasil uji kemampuan belajar tikus percobaan

\section{Kesimpulan}

Kadar iodum pada ransum perlakuan tanpa KI-TRL 0\%; dengan KI-TRL 0\%; tanpa KI-TRL 5\% dan perlakuan tanpa KI-TRL 10\%, masing-masing adalah 5,78, 23,05, 22,96 dan 37,76 ppm. Perbedaan kadar iodium pada ransum tidak berpengaruh nyata terhadap pertambahan berat badan tikus percobaan, namun berpengaruh nyata terhadap daya serap dan retensi iodium, jumlah sel neuron otak, serta kemampuan belajar tikus percobaan.

Hasil penelitian menunjukkan bahwa rata-rata jumlah iodium yang ditahan tubuh tikus per hari pada masing-masing perlakuan adalah: 43,75 $\mu \mathrm{g}$ (tanpa KI-TRL 0\%); 242,33 $\mu \mathrm{g}$ (KI-TRL 0\%); 190,73 $\mu \mathrm{g}$ (tanpa KI-TRL $5 \%$ ) dan 358,09 $\mu \mathrm{g}$ (tanpa KI-TRL 10\%). Jumlah iodium yang ditahan oleh tubuh dipengaruhi oleh jumlah iodium yang disuplai ke dalam tubuh. Semakin banyak suplai iodium maka yang ditahan tubuh semakin banyak.

Kadar iodium dalam ransum berpengaruh terhadap jumlah sel neuron otak tikus. Semakin banyak iodium yang ditahan tubuh maka semakin banyak jumlah sel neuron otak. Rata-rata jumlah sel neuron otak kiri tikus per lapang pandang dengan pembesaran 110x untuk perlakuan ransum tanpa KI-TRL 0\%; KI-TRL 0\%; tanpa KI-TRL 5\% dan perlakuan tanpa KI-TRL $10 \%$ adalah masingmasing 77,42, 92,08, 95,17 dan 100,83. Jumlah sel neuron mempunyai korelasi positif terhadap kemampuan belajar tikus percobaan. Jumlah sel neuron yang lebih banyak memperlihatkan kemampuan belajar yang lebih tinggi, terlihat dari waktu tempuh mendapatkan makanan yang semakin singkat. Waktu tempuh yang diperlukan oleh tikus perlakuan ransum tanpa KI-TRL 0\%, dengan KI-TRL 0\%, tanpa KITRL 5\%, tanpa KI-TRL 10\%, secara berturutturut adalah $57,84,38,17,33,39$ dan 20,55 detik.

\section{Saran}

Dalam penelitian ini, belum dilakukan analisis hormon $\mathrm{T}_{4}$ (tiroksin) dalam darah untuk mengetahui status hipo/hipertiroidisme. Oleh karena itu, perlu dilakukan penelitian lebih lanjut mengenai kadar hormon tersebut di dalam darah. Selain itu perlu juga dilakukan pengukuran kerapatan sel neuron otak secara kuantitatif.

\section{Ucapan Terima Kasih}

Penelitian ini merupakan bagian dari Penelitian Hibah Bersaing XI tahun 2003 yang didanai oleh Proyek Pengkajian dan Penelitian Ilmu Pengetahuan Terapan dari Direktorat Pembinaan Penelitian dan Pengabdian pada Masyarakat, Direktorat Jenderal Pendidikan Tinggi, Departemen Pendidikan Nasional. 
Astawan, et al.

\section{Daftar Pustaka}

AOAC. 1995. Official Methods of Analysis of The AOAC Inc., Arlington, Virginia.

Asp, N.G., Johansson, C.G., Hallmer, H. and Siljestrom, M. 1983. Rapid enzymatic assay of insoluble and soluble dietary fiber. J. Agric. Food Chem. 31: 476-482

Astawan, M. dan Palupi, N.S. 1990. Bahan Pengajaran: Serat Makanan. Laboratorium Kimia Biokimia Pangan, Pusat Antar Universitas Pangan dan Gizi, Institut Pertanian Bogor. Bogor.

Djokomoeljanto, R. 1993. Gangguan Akibat Kekurangan Iodium Pada Umumnya, Khususnya di Indonesia dan Beberapa Masalahnya. Makalah disampaikan dalam Kursus Singkat Iodium Mikronutrien Esensial, di Universitas Gajah Mada. Yogyakarta.

Hetzel, B.S and Clugston, G.A. 1994. Iodine. Di dalam Shils, M.E, J.A. Olson dan M. Shike. Modern Nutrition in Health and Disease. Vol. 1. Lea \& Febiger, Tokyo.

Mahan, L.K. and Stump, S.E. 1996. Food, Nutrition and Diet Therapy. $9^{\text {th }}$ edition. W.B Saunders Company. Philadelphia-London-Toronto.
Nurhidayat. 1992. Pengamatan Beberapa Aspek Makr dan Mikro Anatomi Otak Tikus (Rattus sp Akibat Perlakuan Hipotiroidisme Juvenil da Pengujian Menggunakan T-maze. Tesi Program Pasca Sarjana, Institut Pertania Bogor. Bogor.

Raghuramulu, N. K., Madhawan, N. dan Sundaran, S. K 1983. A Manual of Laboratory Technique National Institut of Nutrition, Hyderabac India.

Sediaoetama, A D. 1991. Ilmu Gizi (Jilid 2) Dian Rakya Jakarta.

Suprijana, O. 1992. Effect of The Type of Fat in The Di in Learning Ability and Brain Fatty Aci Composition in Rats. Dissertation. Univerit of Indonesia. Jakarta.

Susanto, A. 2000. Pengaruh Suplementasi Seleniun Metionin dan Iodium Terhadap Pertumbuha dan Kecerdasan Anak Tikus Dari Indu Kekurangan Iodium. Disertasi. Program Pasc Sarjana, Institut Pertanian Bogor. Bogor.

Winarno, F. G. 1997. Kimia Pangan dan Gizi, P Gramedia. Jakarta. 